\title{
Pemetaan Kerusakan Terumbu Karang Akibat Kandasnya Kapal Tongkang di Taman Nasional Karimunjawa, Jawa Tengah
}

\author{
Munasik $^{1^{\star}}$, Muhammad Helmi ${ }^{2}$, Rikoh Manogar Siringoringo ${ }^{3}$, Suharsono ${ }^{3}$ \\ ${ }^{1}$ Departemen IImu Kelautan, Fakultas Perikanan dan Ilmu Kelautan, Universitas Diponegoro \\ ${ }^{2}$ Departemen Oseanografi, Fakultas Perikanan dan IImu Kelautan, Universitas Diponegoro \\ JI. Prof. H. Soedarto S.H, Tembalang, Semarang, Jawa Tengah 50275 Indonesia \\ ${ }^{3}$ Pusat Penelitian Oseanografi Lembaga Ilmu Pengetahuan Indonesia \\ Jl. Pasir Putih I/1 Ancol Timur. Jakarta 14430 Indonesia \\ *Corresponding author, e-mail : munasik@live.undip.ac.id
}

\begin{abstract}
ABSTRAK: Pemetaan kerusakan terumbu karang akibat kandasnya kapal tongkang di $P$. Tengah dan di P. Cilik, Taman Nasional Karimunjawa, Jawa Tengah telah dilakukan 2-3 bulan setelah kejadian dengan cara mengukur luas area kerusakan dan menilai kondisi terumbu karang. Pengukuran area kerusakan menggunakan metode penginderaan jarak jauh berbasis Drone (UAV Drone/pesawat tanpa awak) dan penilaian kondisi ekosistem terumbu karang dengan menggunakan metode Underwater Photo Transect (UPT). Tujuan penelitian ini adalah untuk mengetahui kondisi dan kerusakan terumbu karang akibat kandasnya kapal tongkang di $P$. Cilik dan P. Tengah, Taman Nasional Karimunjawa. Hasil menunjukkan telah terjadi kerusakan fisik di lereng atas terumbu karang pada kedua pulau tersebut berupa karang mati dan pecahan karang. Luas kerusakan terumbu karang di $\mathrm{P}$. Tengah $\left(1.420,32 \mathrm{~m}^{2}\right)$ lima kali lebih luas daripada luas kerusakan terumbu karang di $\mathrm{P}$. Cilik $\left(267,22 \mathrm{~m}^{2}\right)$. Luasnya kerusakan terumbu karang di $\mathrm{P}$. Tengah kemungkinan akibat perbedaan jumlah kapal tongkang yang kandas, waktu kandas dan dominasi karang yang mudah patah (fragile). Komunitas karang keras yang dominan di lereng terumbu P. Tengah adalah karang bercabang (CB), Acropora bercabang (ACB) dan karang lembaran/foliose (CF). Luasan kerusakan dan kondisi terumbu karang akibat kandasnya kapal tongkang ini dapat digunakan untuk pengelola kawasan konservasi dalam perencanaan perlindungan dan restorasi ekosistem terumbu karang di Taman Nasional Karimunjawa
\end{abstract}

Kata kunci: terumbu karang; kapal tongkang; drone; tutupan karang hidup

\section{Mapping of damage to coral reefs due to barges grounding at Karimunjawa National Park, Central Java}

\begin{abstract}
Mapping damage to coral reefs due to the barges grounding in Cilik Island (P. Cilik) and Tengah Island (P. Tengah), Karimunjawa National Park, Central Java was carried out 2-3 months after the event by measuring the extent of damage and coral reefs assessment. Damage area measurement using Drone (UAV Drone) based remote sensing and reef ecosystem assessment using the Underwater Photo Transect (UPT) method. The aim of this study was to determine the condition and damage of coral reefs due to the wrecking of barges in Cilik and Central P., Karimunjawa National Park The results show that physical damage has occurred on the upper slopes of coral reefs on both islands is dead coral and coral fragments. Damage to extensive coral reefs in $P$. Tengah $\left(1,420.32 \mathrm{~m}^{2}\right)$ is five times larger than extensive damage to coral reefs in $P$. Cilik $\left(267.22 \mathrm{~m}^{2}\right)$. Damage to coral reefs in $P$. Tengah may cause differences in the number of barges that ran aground, time of aground and the dominance of fragile corals the upper slopes of the coral reefs. The dominant hard coral communities on the upper slopes of $P$. Tengah reefs are generally composed the fragile corals, such as branching corals (CB), branching Acropora (ACB) and foliose corals (CF). Damage to coral reefs and the condition of the ecosystem caused by the aground of the barges can be used to manage conservation areas in the planning of conservation and restoration of coral reef ecosystems in the Karimunjawa National Park in near future.
\end{abstract}

Keywords: coral reefs; barges grounding; drone; remote sensing; percentage of coral cover 


\section{PENDAHULUAN}

Terumbu karang merupakan ekosistem yang umum ditemukan di perairan tropis seperti Indonesia. Keberadaannya memiliki nilai produktivitas, fungsi ekonomis dan fungsi ekologis yang tinggi bagi lingkungan sekitar ekosistem maupun untuk manusia (Wilkinson, 2000). Terumbu karang di Kepulauan Karimunjawa ditemukan hampir di seluruh pulau dengan kisaran tutupan karang hidup sebesar 7-69\% (Nababan et al., 2010). Rata-rata tutupan karang hidup di Kepulauan Karimunjawa adalah $54,6 \%$. Jumlah genera karang keras yang menyusun ekosistem terumbu karang adalah 69 genera karang keras (Ordo Scleractinia) dan 3 ordo non-Scleractinia. Tingginya keanekaragaman hayati perairan Karimunjawa serta lengkapnya ekosistem pesisir dan pulaupulau kecil sehingga kawasan ini ditetapkan sebagai Kawasan konservasi Taman Nasional Karimunjawa berdasarkan Surat Keputusan Menteri Kehutanan dan Perkebunan No. 78/ KptsII/1999 seluas 111.625 hektar terbagi luas perairan 110.117,3 hektar dan 1.507,7 hektar dan dikelola dengan sistem zonasi.

Akhir-akhir ini perairan Taman Nasional Karimunjawa telah menjadi jalur lalu lintas kapalkapal karena letaknya di persimpangan lalu lintas kapal niaga di Laut Jawa sehingga hal ini berpotensi terjadi kecelakaan kapal kandas di area terumbu karang (Yusidarta \& Atmojo, 2018). Kejadian pertama kandasnya kapal tongkang di perairan Taman Nasional Karimunjawa yaitu didapatinya Kapal Tongkang (Barge) BG Sinar Anugerah 2503 yang kandas di perairan sisi barat Pulau Cilik pada 14 Januari 2017 yang mengakibatkan kerusakan pada terumbu karang. Selanjutnya pada 10 Februari 2017, sebanyak 4 (empat) kapal tongkang, yaitu BG. Charles 206, BG. PST 210, BG. Marine 70, BG. RMN 374 juga menyusul kandas di perairan sisi barat Pulau Tengah yang mengakibatkan kerusakan yang luas pada terumbu karang di perairan tersebut. Permasalahan terjadi bagaimana memetakan kerusakan terumbu karang baik dari aspek luas maupun kondisi terumbu karang, mengingat luasnya kerusakan yang diakibatkan. Metode penentuan kerusakan terumbu karang yang sudah diaplikasikan adalah metode fishbone (Collier et al., 2007), akan tetapi cara ini hanya bertujuan untuk mengestimasi kerusakan secara cepat di area yang relatif sempit. Untuk kerusakan yang massif, seperti di P. Tengah ini diperlukan metode yang sesuai untuk pengukuran luas kerusakan.

Akhir-akhir ini penggunaan teknologi penginderaan jauh berbasis citra satelit telah banyak digunakan untuk kajian pemetaan dan monitoring perubahan lingkungan, perubahan ekosistem hutan (Johansen et al., 2007), kejadian tumpahan minyak (Brekke \& Solberg, 2005). Teknologi penginderaan jauh juga sangat efektif untuk penyediaan data monitoring dan pengelolaan pesisir (Dahdouh-Guebas, 2002), analisis ekosistem bentik dan terumbu karang (Helmi et al., 2020). Aplikasi penginderaan jauh untuk skala lokal dan sempit membutuhkan data spasial dengan resolusi tinggi dan membutuhkan biaya yang tinggi. Teknologi penginderaan jauh berbasis Drone juga telah banyak digunakan untuk analisis spasial di wilayah pesisir dan perairan dangkal seperti pemetaan habitat lamun, daerah asuhan ikan (Ventura et al., 2016). Pemetaan kerusakan terumbu karang yang luas akibat kandasnya kapal tongkang ini telah diaplikasikan secara tidak langsung dengan menggunakan teknologi penginderaan jauh berbasis pesawat tanpa awak atau Drone sederhana dan menilai (assessment) kondisi terumbu karang di area terdampak.

\section{MATERI DAN METODE}

Penelitian dilakukan pada area terdampak dan di luar area terdampak terumbu karang yang tertabrak kapal tongkang di sisi barat Pulau Cilik, Taman Nasional Karimunjawa (5'49'15" 549'23" LS; $110^{\circ} 30^{\prime} 24^{\prime \prime}-110^{\circ} 30^{\prime} 31^{\prime \prime}$ BT), akibat kandasnya kapal tongkang (Barge) Sinar Anugerah 250314 Januari 2017. Penelitian juga dilakukan pada area terdampak dan di luar area terdampak terumbu karang yang tertabrak kapal Tongkang di sisi barat Pulau Tengah $\left(5^{\circ} 48,262^{\prime}\right.$ LS- $110^{\circ} 30.415^{\prime}$ BT; $5^{\circ} 48.511^{\prime}$ LS- $110^{\circ} 30.370^{\prime}$ BT) akibat kandasnya 4 (empat) kapal tongkang (Barge) BG. Charles 206, BG. PST 210, BG RMN 37410 Februari 2017 (Gambar 1),

Identifikasi kerusakan terumbu karang di Pulau Cilik dan Pulau Tengah tersebut telah dilakukan melalui pengamatan secara langsung dan tidak langsung. Pengamatan langsung dilakukan melalui survei di lapangan dan pengukuran tidak langsung dilakukan berdasarkan analisis data penginderaan jauh berbasis Drone pada 26-27 April 2017. 


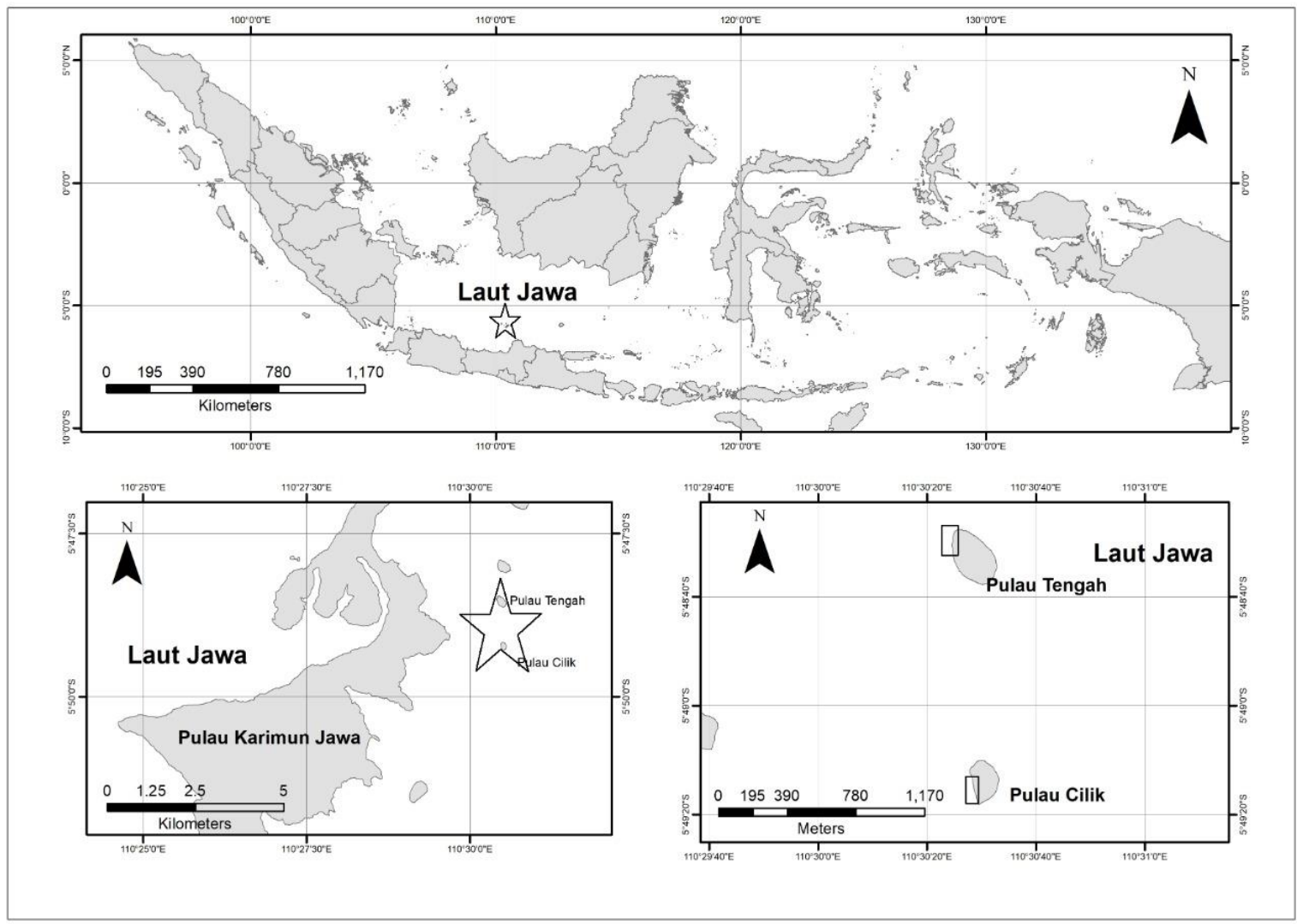

Survei lapangan pengukuran luas terumbu karang dilakukan dengan melakukan marking titik referensi dan batas area terdampak serta perekaman dengan bantuan pesawat tanpa awak/Drone. Survei lapangan juga untuk melakukan studi kondisi ekosistem terumbu karang di area terdampak dan di luar area dampak kerusakan terumbu karang akibat kandasnya kapal tongkang.

Gambar 1. Peta lokasi penelitian di Pulau Cilik dan Pulau Tengah, Kepulauan Karimunjawa, Jawa Tengah

\section{Pengukuran Area Terumbu Karang Terdampak}

Pengukuran area terumbu karang terdampak dilakukan dengan metode penginderaan jauh berbasis Drone (pesawat tanpa awak), yaitu melalui analisis data dari hasil perekaman foto udara dan atau citra satelit. Analisis spasial dalam studi ini dilakukan dengan menggunakan foto udara format kecil yang direkam menggunakan wahana UAV (Unmanned Aerial Vehicles) Drone atau pesawat tanpa awak. Karena area terumbu terdampak yang relatif luas dan membutuhkan tingkat kedetailan informasi spasial yang tinggi pasca kejadian, maka digunakan UAV Drone. Data yang dihasilkan dari perekaman UAV Drone adalah foto udara berwarna format kecil dengan resolusi sangat tinggi $(15 \times 15 \mathrm{~cm})$. Foto udara dilakukan dengan menggunakan Drone Phantom 3 yang diterbangkan pada ketinggian $350 \mathrm{~m}$ dan $20 \mathrm{~m}$ diatas permukaan laut perairan P. Cilik dan P. Tengah yang terkena dampak. Pengukuran langsung dilakukan di perairan dengan mengukur langsung di perairan secara detail titik-titik terluar area terumbu karang yang terdampak. Pengukuran dilakukan oleh penyelam snorkeling yang melakukan marking (penandaan) pada titiktitik terluar area terdampak dengan menggunakan GPS (Global Positioning System). Sebelum dilakukan marking titik-titik batas terluar, terlebih dulu dilakukan penandaan batas sebanyak 4 (empat) titik pada ujung areal terumbu karang terdampak dengan menggunakan buoy. Snorkeling dimulai dari titik referensi berupa patok bambu yang telah diketahui koordinatnya menuju buoy di ujung batas area. Untuk meyakinkan akurasi batas-batas area terdampak, penyelam snorkel dibantu oleh seorang penyelam SCUBA hingga memungkinkan sampai kedalaman terumbu 
karang. Data posisi yang diperoleh kemudian disimpan pada GPS untuk dilanjutkan analisis spasial. Selanjutnya analisis spasial luas area terdampak dilakukan dengan tahapan interpretasi dan deliniasi area kerusakan, pemetaan area terdampak dan verifikasi berdasarkan data survei, serta perhitungan luas area terdampak.

\section{Kondisi Terumbu Karang}

Pengambilan data utama berupa tutupan karang hidup dilaksanakan menggunakan metode UPT (Underwater Photo Transect; Giyanto et al., 2010; Giyanto, 2012a; Giyanto, 2012b). UPT adalah metode pengambilan data tutupan karang hidup menggunakan alat bantu frame berukuran $58 \times 44 \mathrm{~cm}$ yang dipasang pada garis transek sepanjang 50 meter dengan cara pemotretan yang selanjutnya akan dianalisis melalui aplikasi image analysis. Pengambilan data menggunakan metode UPT dilakukan dengan penyelaman SCUBA, pemotretan menggunakan kamera beresolusi tinggi yang dilengkapi dengan housing yang kompatibel untuk kegiatan penyelaman serta frame besi berbentuk persegi yang diberi warna mencolok (Suharsono \& Sumadhiharga, 2014) Selanjutnya dilakukan pengambilan data kondisi terumbu karang di area terdampak P. Cilik (Stasiun 1) dan di luar area terdampak P. Cilik (Stasiun 2; Gambar 2a) Sedangkan di P. Tengah area terdampak (Stasiun 3 dan 4; Gambar 2.b) dan di luar area terdampak (Stasiun 5 dan 6).

Frame besi diterapkan pada transek garis $50 \mathrm{~m}$ dengan interval jarak $1 \mathrm{~m}$ yang dimulai pada titik $0 \mathrm{~m}$ (angka genap) frame diletakkan disebelah kanan atau sebelah bawah garis transek dan pada setiap angka ganjil berada disebelah kiri atau berada di atas garis transek dan seterusnya (Gambar 3), sehingga diperoleh sebanyak 50 eksposur foto untuk setiap stasiun. Selanjutnya data yang dihasilkan sebanyak 50 foto tersebut dianalisa menggunakan piranti lunak CPCe (Coral Point Count with Excel extension) versi 4.1. (Kohler \& Gill, 2006). Substrat dasar terumbu karang yang di area terdampak dan di luar area terdampak diidentifikasi hingga tingkat lifeform serta jenis-jenis karang keras penyusun utama didokumentasikan dengan menggunakan kamera digital bawah air.

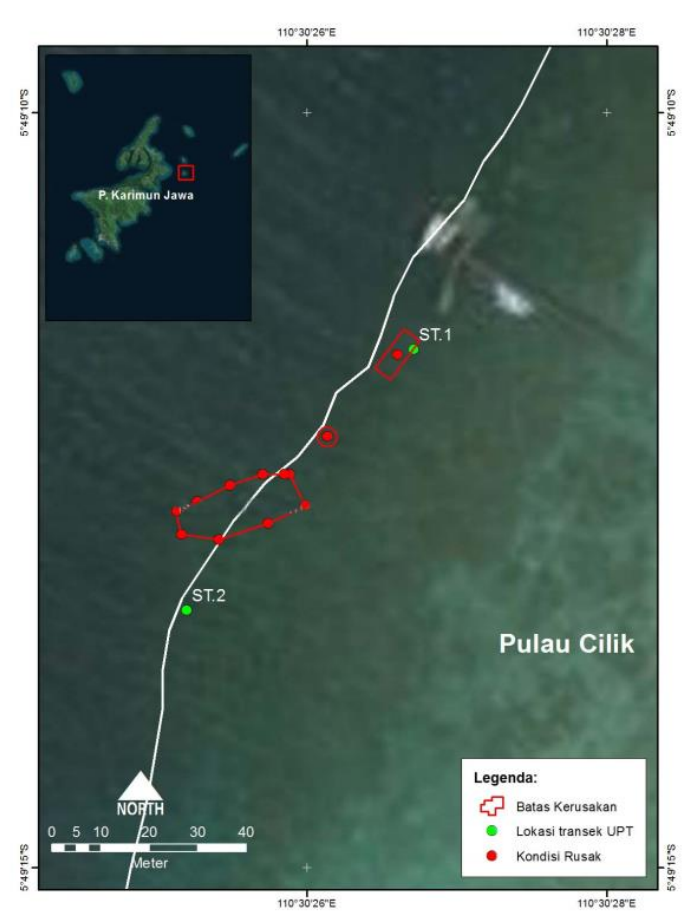

(a)

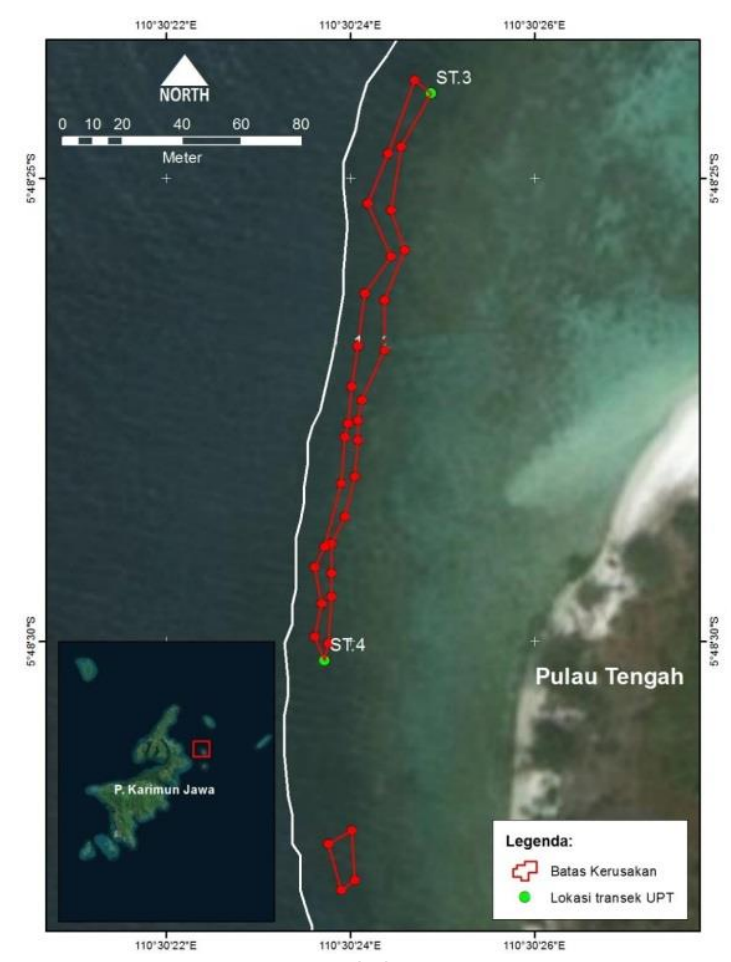

(b)

Gambar 2. Lokasi Survei Kondisi Terumbu Karang (a) di Pulau Cilik, (b) P. Tengah Taman Nasional Karimunjawa 


\section{Analisis Data}

Analisis foto hasil pemotretan dilakukan menggunakan komputer dan piranti lunak (software) CPCe (Giyanto, 2012a; 2012b). Sebanyak 30 sampel titik acak dipilih untuk setiap frame foto, dan untuk setiap titiknya diberi kode sesuai dengan kode masing-masing kategori dan biota dan substrat yang berada pada titik acak tersebut (Tabel 1). Hasil analisis akan diperoleh persentase tutupan untuk setiap kategori bentuk pertumbuhan (lifeform) substrat dasar/bentik (English et al., 1997) yang berada di sepanjang garis transek pada masing-masing stasiun pengamatan.

Selanjutnya dihitung persentase tutupan masing-masing kategori biota dan substrat untuk setiap frame foto menggunakan rumus persentase tutupan kategori adalah jumlah titik kategori tersebut dibagi dengan banyaknya titik acak dikalikan 100\%. Berdasarkan nilai persentase tutupan karang hidup dapat ditentukan kondisi terumbu karang sesuai dengan SK Menteri Lingkungan Hidup No. 04/2001.

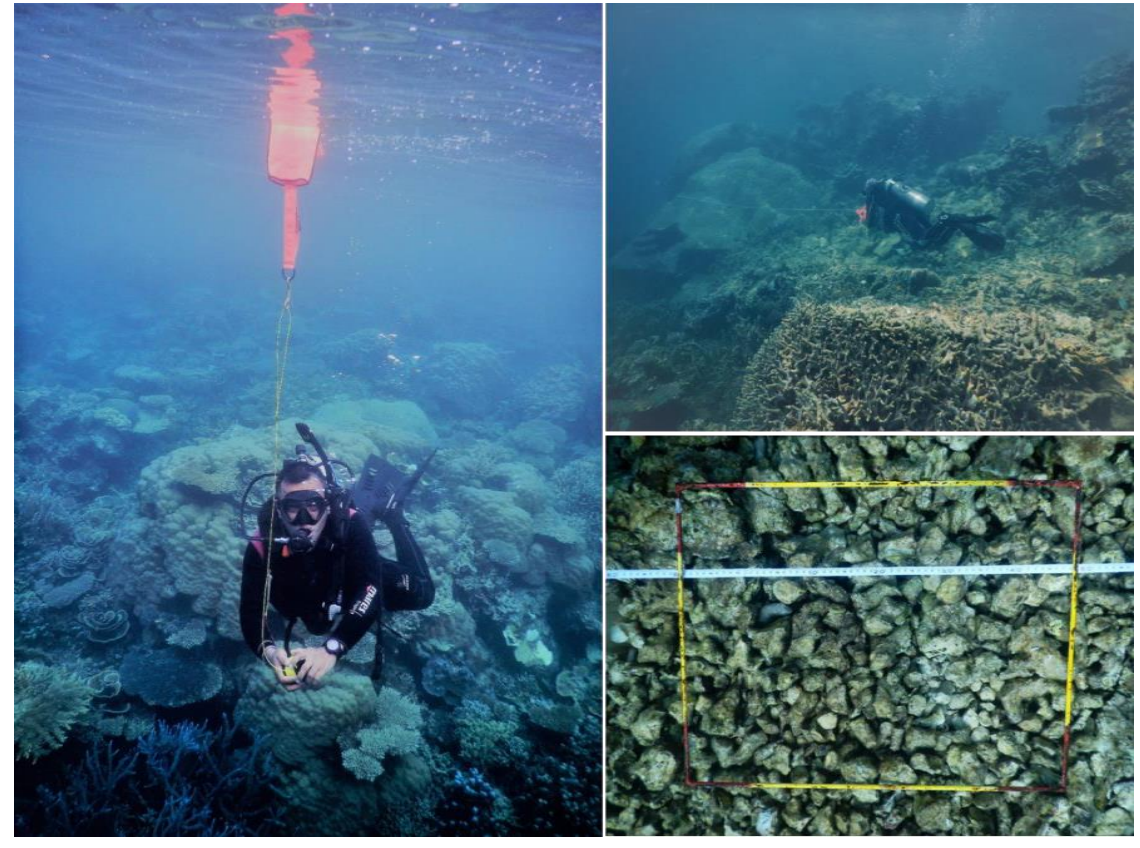

Gambar 3. Metode penetapan titik survei dan metode pengambilan data kondisi terumbu karang dengan metode UPT

Tabel 1. Kode kategori biota dan substrat dasar (lifeform) terumbu karang

\begin{tabular}{ll}
\hline Kode Kategori & Keterangan \\
\hline LC & Live Coral = Karang batu hidup = karang hidup = AC+NA \\
- AC & Acropora = karang batu marga Acropora \\
- NA & Non Acropora = karang batu selain marga Acropora \\
DC & Dead Coral = karang mati \\
DCA & Dead Coral with Algae = karang mati yang telah ditumbuhi alga \\
SC & Soft Coral = karang lunak \\
SP & Sponge = spons \\
FS & Fleshy Seaweed = alga \\
OT & Other Fauna = fauna lain \\
R & Rubble = pecahan karang \\
S & Sand = pasir \\
SI & Silt = lumpur \\
RK & Rock = batuan \\
\hline
\end{tabular}




\section{HASIL DAN PEMBAHASAN}

Area terumbu karang terdampak adalah area terumbu karang yang rusak, dicirikan oleh kerusakan fisik terumbu dengan mortalitas 100\%, kerusakan terlihat dari jejak kandasnya kapal tongkang yang membentuk alur bekas badan kapal yang menabrak dan melindas. Koloni-koloni karang yang terpotong di kedalaman $4 \mathrm{~m}$ dan beberapa bongkahan koloni karang runtuh hingga ke lereng terumbu yang lebih dalam hingga mencapai kedalaman 6-10 m di luar area terdampak. Hasil pengukuran kerusakan terumbu karang yang dibatasi oleh titik-titik terluar area terdampak dilanjutkan analisis foto udara dengan bantuan UAV Drone yang ditumpang susunkan dengan citra satelit GeoEye maka area terumbu karang terdampak di Pulau Cilik sebesar 267,22 $\mathrm{m}^{2}$ (Gambar 4) dan di Pulau Tengah sebesar 1.420,32 $\mathrm{m}^{2}$ (Gambar 5). Area terdampak di P. Cilik terdiri dari 3 kelompok kecil sedangkan di $P$. Tengah terdiri satu area kerusakan yang memanjang mengikuti punggung terumbu. Luas area terdampak terumbu karang di $P$. Tengah lebih luas lima kali dibanding area terdampak pada terumbu karang P. Cilik. Luas kerusakan terumbu karang di P. Tengah paling tinggi diantara luas kerusakan akibat kapal tongkang di tempat lain di Karimunjawa. Luas terumbu karang yang rusak di Gosong Seloka akibat kandasnya kapal tongkang hanya mencapai 184,45 $\mathrm{m}^{2}$ (Yusidarta \& Atmojo, 2018). Ada beberapa hal yang mengakibatkan perbedaan luasan area terdampak (rusak) diantara dua gugusan terumbu karang di kedua pulau tersebut. Pertama, jumlah kapal tongkang yang kandas di P. Tengah lebih banyak daripada di P. Cilik, kedua, waktu kejadian yang berbeda, di P. Tengah terjadi saat air sedang surut sedangkan di P. Cilik terjadi saat air pasang dan ketiga, bentuk terumbu karang tepi di P. Cilik lebih landai daripada P. Tengah.

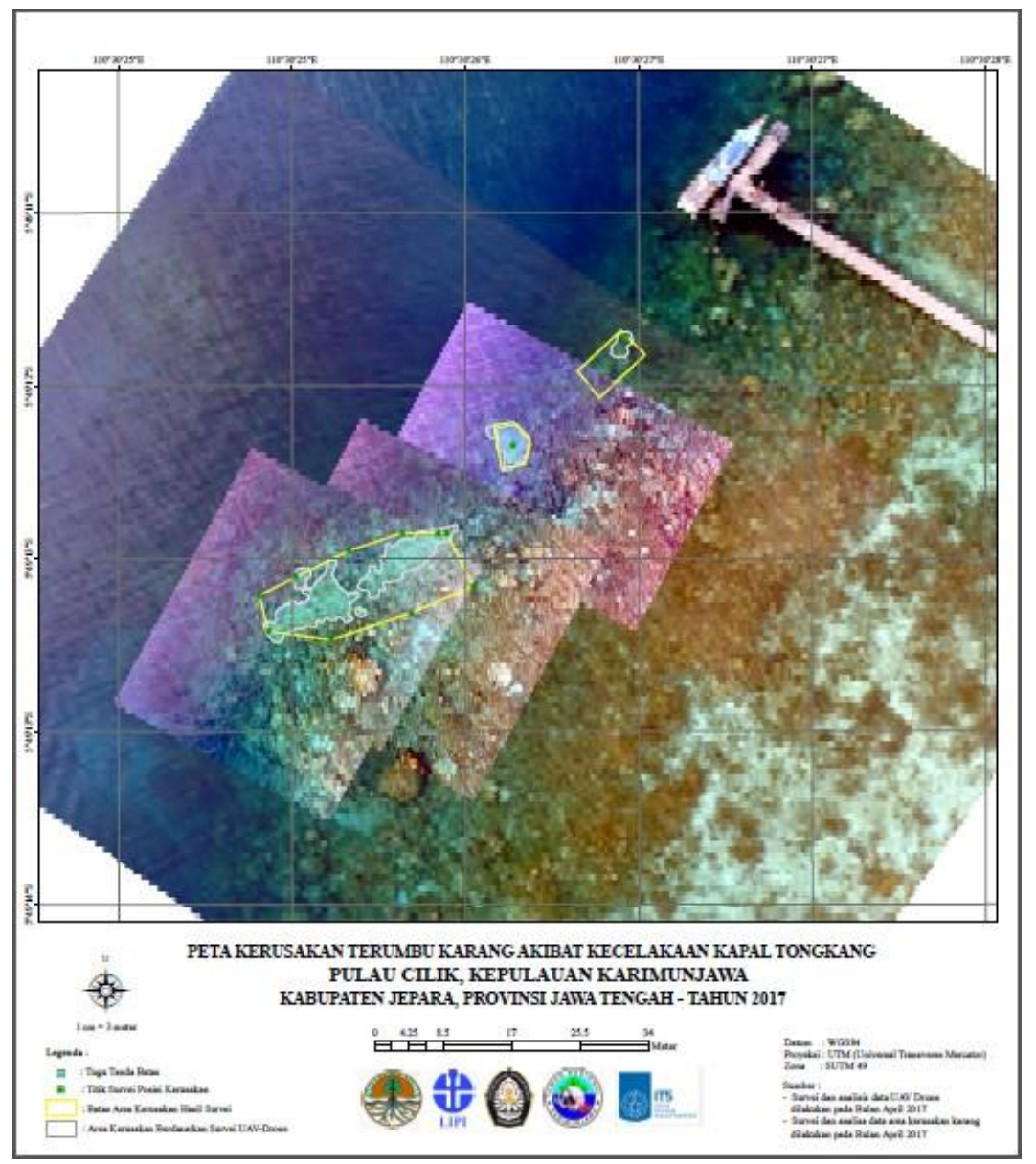

Gambar 4. Peta Kerusakan Terumbu Karang di Pulau Cilik Taman Nasional Karimunjawa 


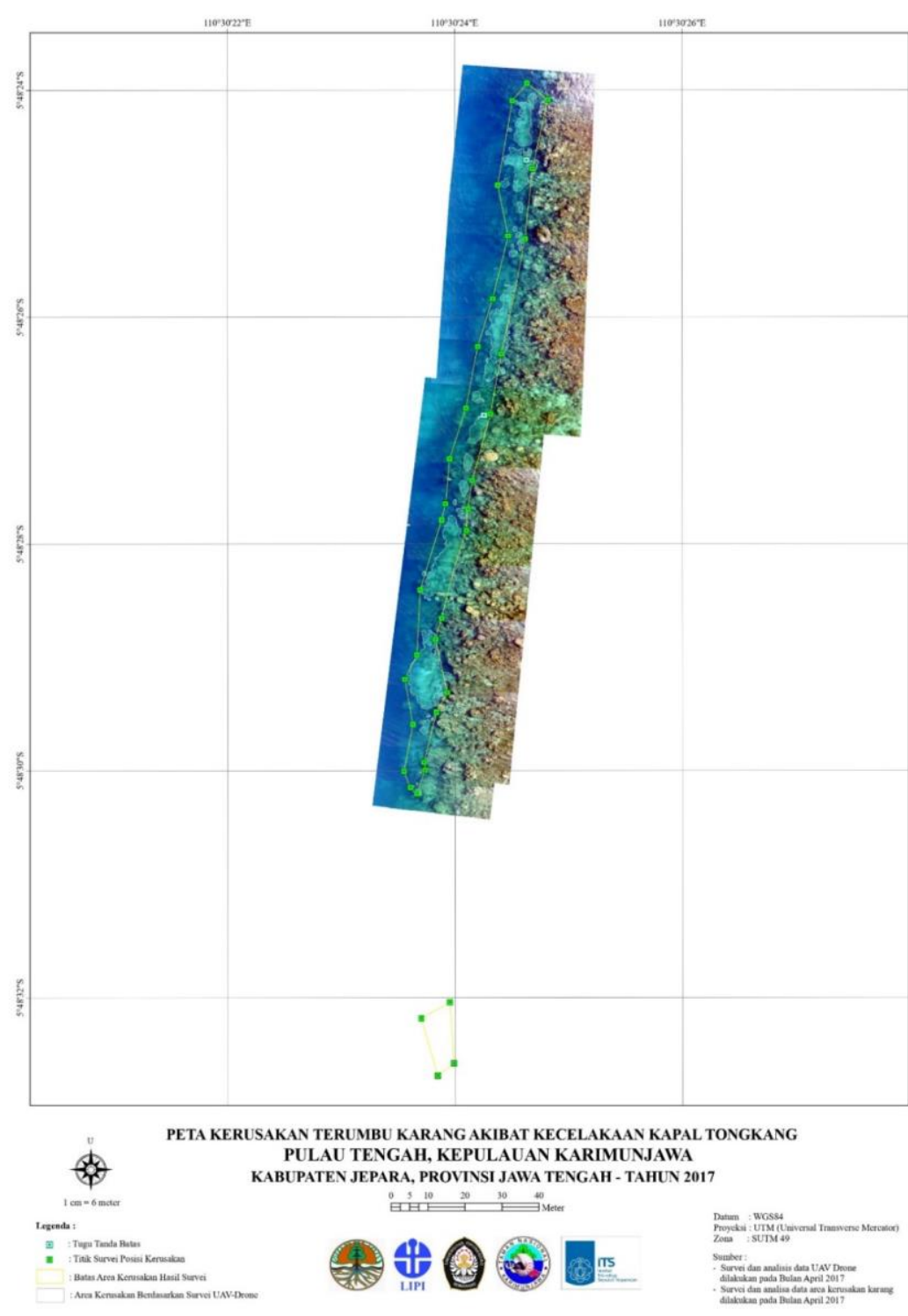

Gambar 5. Peta Kerusakan Terumbu Karang di Pulau Tengah Taman Nasional Karimunjawa

\section{Kondisi Terumbu Karang di P. Cilik}

Kondisi terumbu karang di area terdampak di Pulau Cilik, Kepulauan Karimunjawa menunjukkan kategori rusak, dengan persentase tutupan karang hidup sebesar 41,8 \%. Sisanya, lebih dari sepertiga, 31\% tertutup oleh karang yang baru saja mati (Death Coral/DC) dan selebihnya adalah karang mati yang diselimuti algae (Death Coral with Algae/DCA) yaitu $25 \%$ (Gambar 6). Kondisi terumbu karang di luar area terdampak di Pulau Cilik menunjukkan kategori baik, dengan persentase tutupan karang hidup 51\%. Hampir tidak dijumpai karang yang baru saja mati (Death Coral/DC) yaitu $0,07 \%$. Akan tetapi karang mati yang diselimuti algae (Death Coral with Algae/DCA) ditemukan dengan tutupan yang tinggi hingga $46 \%$. Hal ini menunjukkan bahwa area di luar dampak tidak terjadi kerusakan fisik akibat kandasnya kapal tongkang akan tetapi banyak karang mati telah lama terjadi dan oleh akibat lainnya. Kerusakan terumbu karang di Karimunjawa telah terjadi akibat praktek perikanan yang tidak ramah lingkungan di dalam Kawasan konservasi, baik dengan menggunakan bom maupun sianida (Edinger et al., 2000).

Komposisi karang keras (hard coral/HC) pada area terdampak di P. Cilik memiliki lifeform yg lebih beragam daripada di luar area terdampak. Area terdampak terdapat di lereng atas terumbu karang tepi P. Tengah yang memiliki keragaman jenis karang yang tinggi, akan tetapi 
sangat rentan terhadap kerusakan fisik (Edinger \& Risk., 2000). Penyusun terumbu karang di lereng terumbu P. Tengah terdiri dari utamanya berupa karang Acropora bercabang (Acropora Branching) karang foliose (Coral Foliose), karang sumasif (Coral Submassive; Gambar 7). Karang keras (hard coral) penyusun yang ditemukan di area terdampak ini sesuai dengan jenis karang yang mengalami kerusakan yaitu Porites (bercabang), Porites (submasif) dan Pavona (foliose), beberapa yang rusak adalah Acropora (bercabang), Montipora (foliose) dan Porites (masif). Ciriciri kerusakan koloni komunitas karang penyusun di P. Cilik, yaitu terjadi patahan-patahan karang yang baru pada koloni bagian atas dan beberapa koloni-koloni karang terpotong terbentuk bongkahan koloni karang serta runtuh hingga ke lereng terumbu yang lebih dalam (Gambar 8).

\section{Kondisi Terumbu Karang di P. Tengah}

Kondisi terumbu karang di area terdampak (Stasiun 3 dan 4) di Pulau Tengah, Kepulauan Karimunjawa menunjukkan kategori rusak, dengan persentase tutupan karang hidup rata-rata $39 \%$. Sebagian besar substrat terumbu karang tertutup oleh karang mati yang diselimuti algae (Death Coral with Algae/DCA) dan selebihnya berupa karang yang baru saja mati (Death Coral/DC) yaitu 24\% di Stasiun 3 (Gambar 9). Tutupan karang yang baru saja mati (Death Coral/DC) di Stasiun 4 juga mencapai $26 \%$ dengan persentase tutupan karang mati yang diselimuti algae (Death Coral with Algae/DCA) mencapai 15\%. Hal ini menunjukkan bahwa terumbu karang di Stasiun 3 dan 4 (area terdampak) telah terjadi kerusakan fisik yang baru saja (recently dead) terjadi.

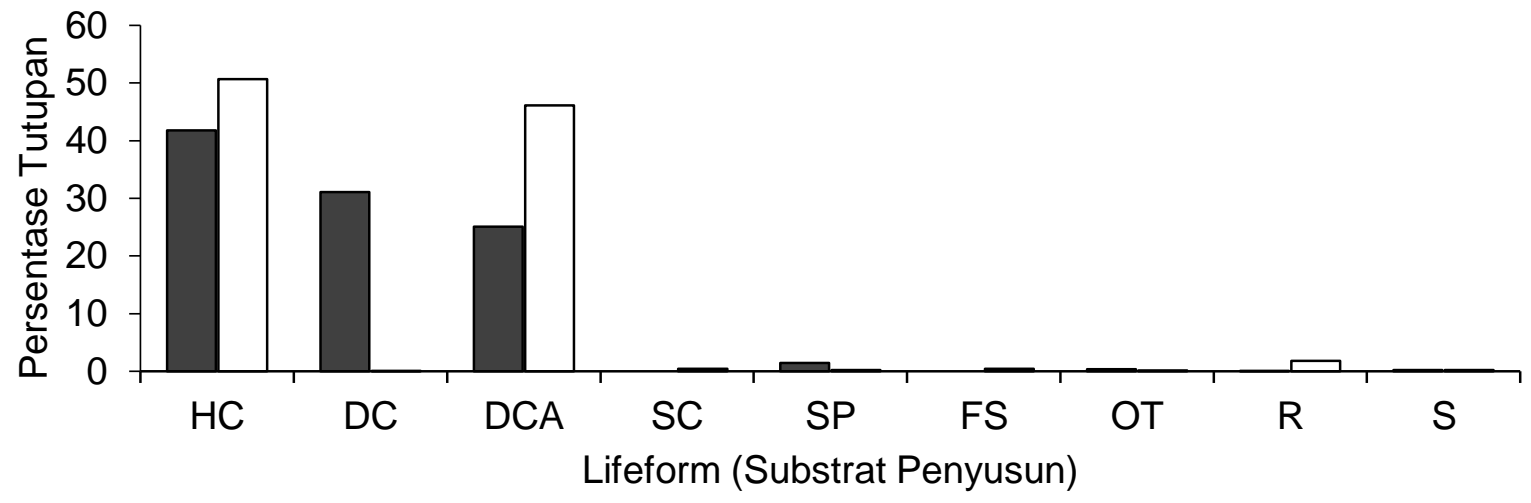

-Area Terdampak $\quad \square$ Area Luar Dampak

Gambar 6. Kondisi terumbu karang di Pulau Cilik berdasarkan lifeform (substrat penyusun)

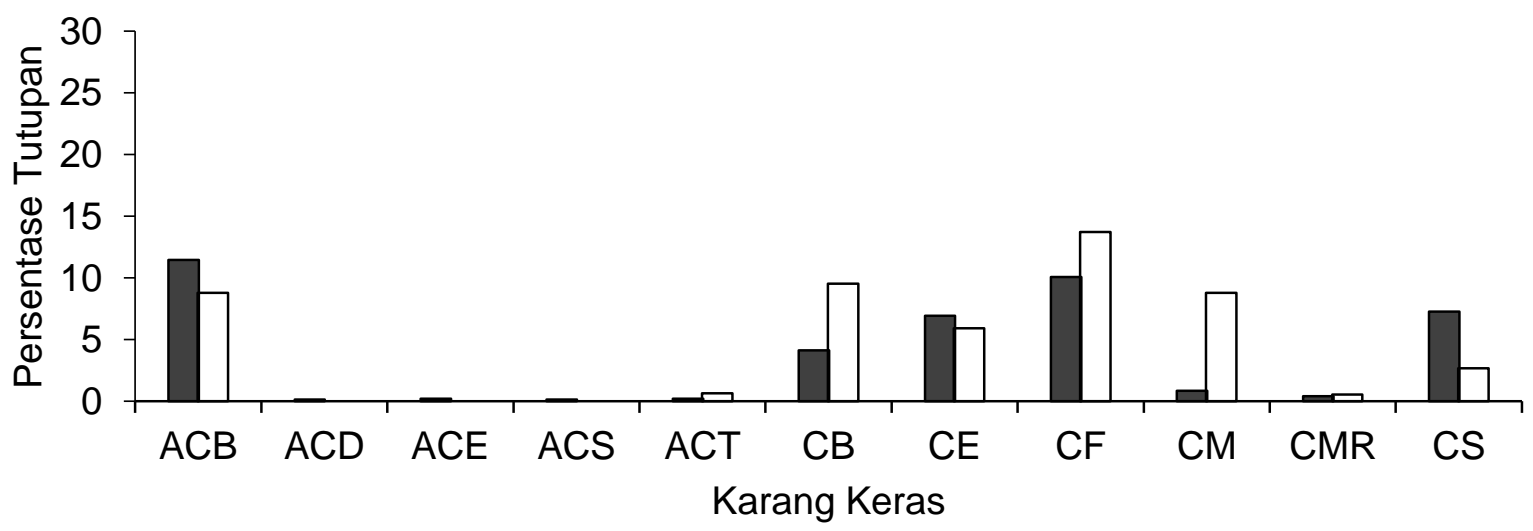

- Area Terdampak $\quad$ A Area Luar Dampak

Gambar 7. Tutupan Karang Hidup (Hard Coral) di Pulau Cilik berdasarkan lifeform 
Kondisi terumbu karang di luar area terdampak (Stasiun 5 dan 6) di Pulau Tengah, Kepulauan Karimunjawa juga menunjukkan kategori rusak, dengan persentase tutupan karang hidup sebesar $41 \%$. Meskipun demikian, rata-rata tutupan karang yang baru saja mati (Death Coral/DC) sangat rendah yaitu $2,4 \%$, ditemukan pula komunitas penyusun terumbu karang lainnya yaitu Sponge (SP) dan Karang lunak (Soft Coral/SC) lebih tinggi pada area di luar terdampak. Hal ini menunjukkan bahwa terumbu karang di luar area terdampak tidak terdapat kerusakan fisik yang baru saja terjadi.

Karang keras (hard coral) penyusun terumbu yang terdapat pada area terdampak dan di luar area terdampak di $\mathrm{P}$. Tengah ini memiliki kesamaan, yaitu umumnya berupa Karang lembaran (Coral Foliose/CF), Acropora bercabang (Acropora Branching/ACB), Karang bercabang (Coral Branching/CB), Karang masif (Coral Massive/CM), Karang mengerak (Coral Encrusting/CE; Gambar 10). Karang keras penyusun utama di area terdampak ini sesuai dengan jenis karang yang mengalami kerusakan yaitu karang Porites bercabang dan Porites masif. Jenis Karang yang rusak didominasi Porites (bercabang) dengan urutan berikutnya adalah Porites (column), beberapa yang rusak adalah Acropora (bercabang), Acropora (tabulate), Pavona (foliose), Pachyseris (crust), Euphyllia, Physogyra dan Porites (masif). Kerusakan terumbu karang di P. Tengah ini terjadi pada jenis karang yang lebih bervariasi dari pada di P. Cilik. Hal ini karena kerusakan terjadi di lereng atas terumbu karang, umumnya lereng atas terumbu tersusun dari berbagai jenis karang yang beragam dan didominasi karang bercabang (Tomasick et al., 1997; Nakamura \& Nakamori, 2009; Takada et al., 2012).

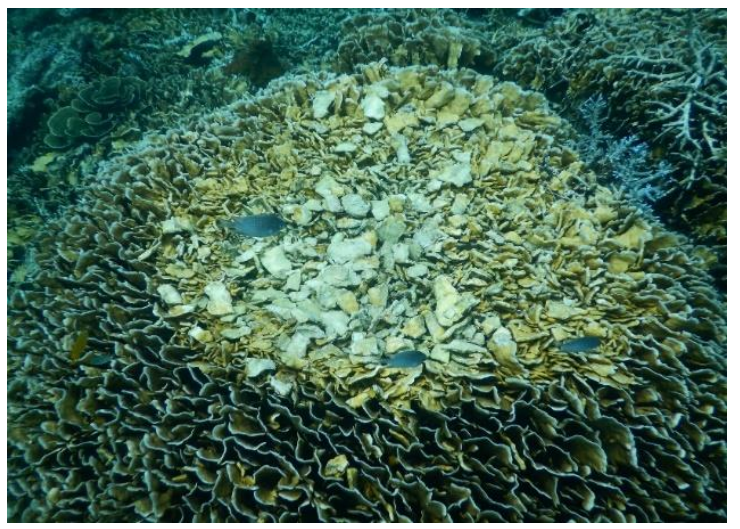

(a)

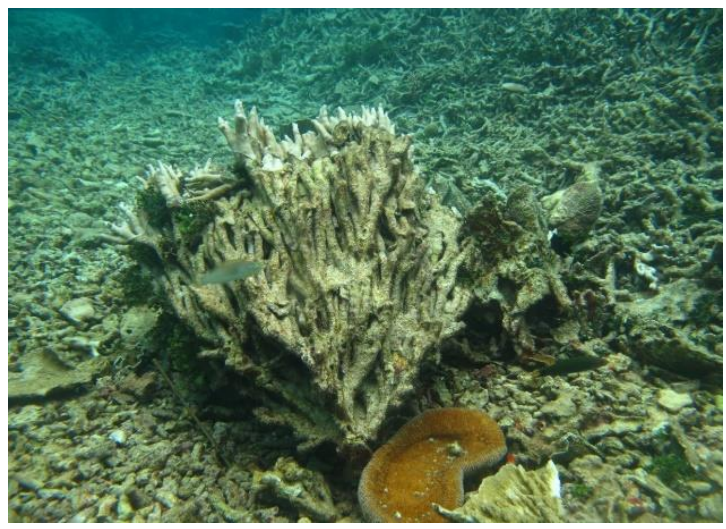

(b)

Gambar 8. Kondisi terumbu karang di area terdampak di Pulau Cilik (a). kerusakan koloni karang foliose, (b) potongan koloni karang yang runtuh

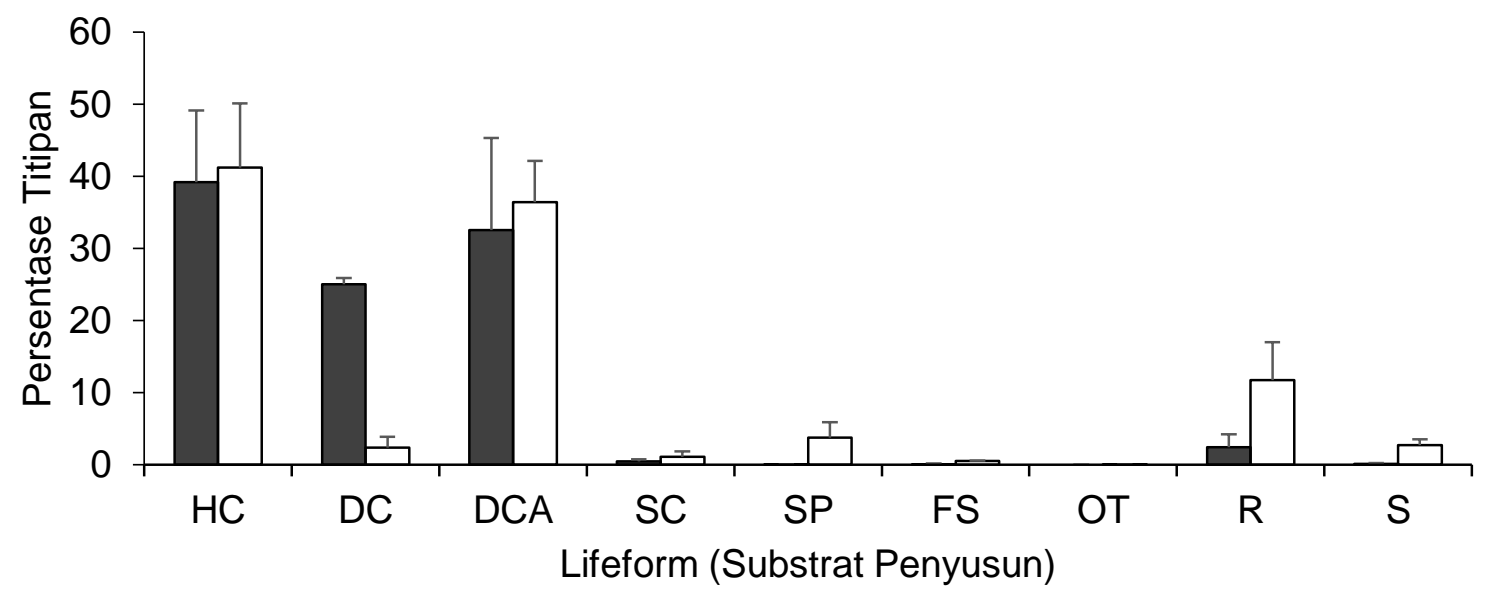

\section{$\square$ Area Terdampak $\quad \square$ Area Luar Dampak}

Gambar 9. Kondisi terumbu karang di Pulau Tengah berdasarkan lifeform (substrat penyusun) 


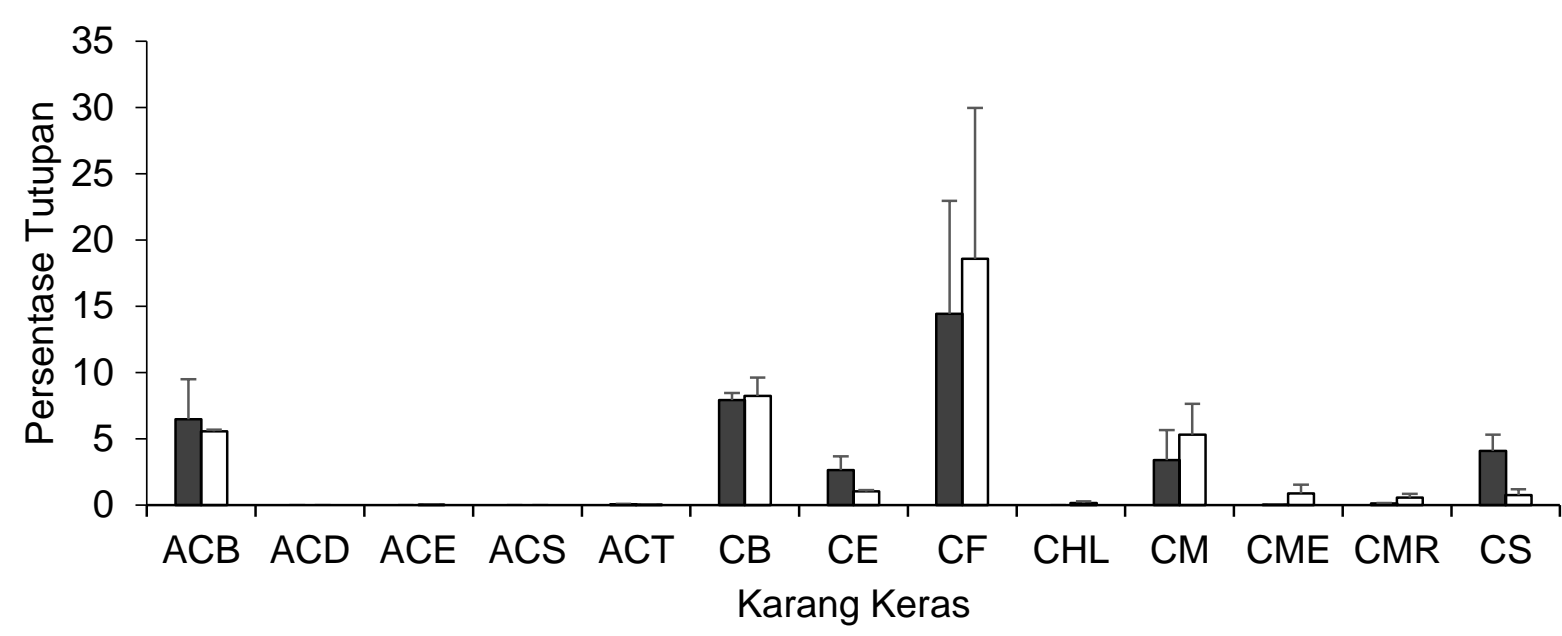

$\square$ Area Terdampak $\quad \square$ Area Luar Dampak

Gambar 10. Tutupan Karang Hidup (Hard Coral) di Pulau Tengah berdasarkan lifeform

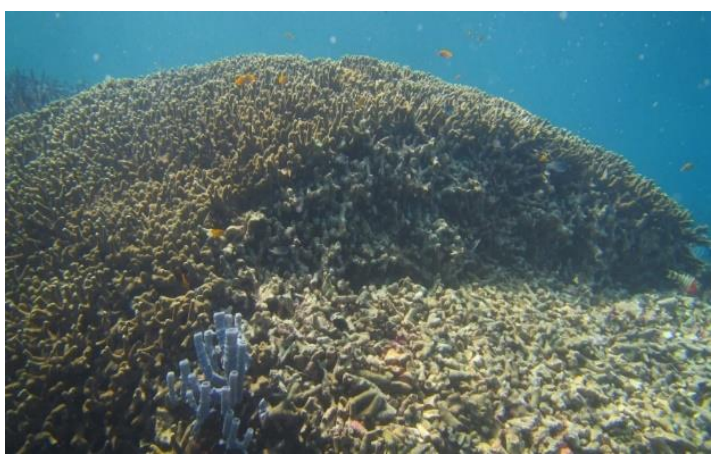

(a)

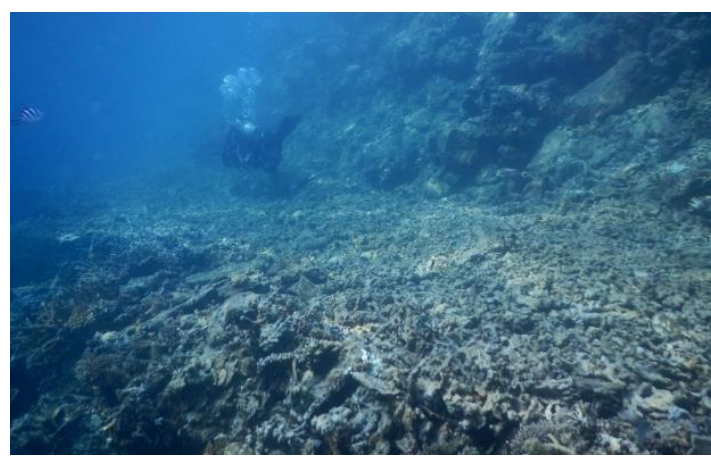

(b)

Gambar 11. Kondisi terumbu karang di area terdampak (rusak) di Pulau Tengah berdasarkan lifeform (a) koloni Porites bercabang yang terpotong; (b) kerusakan pada lereng atas

Ciri-ciri kerusakan pada lereng atas terumbu karang, yaitu terpotonganya koloni karang bercabang pada terumbu karang tepi hingga dasar dan membentuk rataan skeleton karang bercampur dengan patahan karang yang masih baru (Gambar 11). Kerusakan masif pada koloni karang bercabang ini umum terjadi karena bentuk pertumbuhan (lifeform) Coral branching, Acropora branching dan Coral Foliose, meskipun indikasi terumbu karang yang sehat akan tetapi sangat peka terhadap kerusakan fisik (Edinger \& Risk, 2000). Sehingga patahan-patahan koloni karang runtuh hingga ke lereng terumbu yang lebih dalam dan berpotensi merusak komunitas karang sehat lainnya. Hal ini terlihat dari munculnya koloni karang yang baru saja mati (recently dead) di luar area terdampak.

\section{KESIMPULAN}

Area terdampak atau area terumbu karang yang mengalami kerusakan akibat kandasnya kapal tongkang dengan metode penginderaan jauh berbasis UAV Drone di Pulau Cilik sebesar $267,22 \mathrm{~m}^{2}$ (Gambar 4) dan di Pulau Tengah sebesar 1.420,32 $\mathrm{m}^{2}$. Area terdampak di P. Cilik terdiri dari 3 kelompok area kecil sedangkan di P. Tengah terdiri satu area kerusakan yang memanjang mengikuti punggung terumbu. Luas area terdampak terumbu karang di $P$. Tengah lebih luas lima kali dibanding area terdampak pada terumbu karang P. Cilik. Kondisi terumbu karang di area terdampak umumnya tersusun oleh karang yang baru saja mati (Death Coral/DC) dan sebagian 
karang hidup. Jenis-jenis karang keras penyusun terumbu yang mengalami kerusakan di gugusan terumbu karang P. Cilik adalah Porites (bercabang), Porites (submasif) dan Pavona (foliose), beberapa yang rusak adalah Acropora (bercabang), Montipora (foliose) dan Porites (masif). Sedangkan di P. Tengah disamping Porites (bercabang) dan submasif, beberapa yang rusak lainnya adalah Acropora (bercabang), Acropora (tabulate), Pavona (foliose), Pachyseris (crust), Euphyllia, Physogyra dan Porites (masif).

\section{UCAPAN TERIMAKASIH}

Studi ini adalah bagian dari kegiatan verifikasi lapangan kondisi terumbu karang akibat kandasnya kapal tongkang di Pulau Kecil dan Pulau Tengah, Kepulauan Karimunjawa oleh Direktorat Jenderal Penegakan Hukum Lingkungan Hidup dan Kehutanan (Ditjen Gakkum LHK), Kementerian Lingkungan Hidup dan Kehutanan Republik Indonesia.

\section{DAFTAR PUSTAKA}

Brekke, C. \& Solberg, A.H.S. 2005. Oil spill detection by satellite remote sensing. Remote Sensing of Environment, 95(1):1-13. DOI: 10.1016/j.rse.2004.11.015.

Collier, C., Dodge, R., Gilliam, D., Gracie, K., Gregg, L., Jaap, W., Mastry, M. \& Poulos, N. 2007. Rapid Response and Restoration for Coral Reef Injuries in Southeast Florida: Guidelines and Recommendations. The Department of Environmental Protection, 63pp.

Dahdouh-Guerbas, F. 2002. The use remote sensing and GIS in the sustainable management of tropical coastal ecosystems. Environment, Development and Sustainability 4(2): 93-112

Edinger, E.N. \& Risk, M.J., 2000. Reef classification by coral morphology predicts coral reef conservation value. Biological Conservation 92:1-13

Edinger, E.N., Kolasa, J. \& Risk, M.J. 2000. Biogeographic variation in coral species diversity on coral reefs in three regions of Indonesia. Diversity and Distributions 6:113-127

English, S., C. Wilkinson and V. Baker.1994. Survey Manual for Tropical Marine Resources. Australian Institute of Marine Science, Townsville. Australia.

Giyanto, B.H., Iskandar, Soedharma, D. \& Suharsono. 2010. Efisiensi dan akurasi pada proses analisis foto bawah air untuk menilai kondisi terumbu karang. Oseanologi dan Limnologi di Indonesia, 36 (1): 111-130.

Giyanto. 2012a. Kajian tentang panjang transek dan jarak antar pemotretan pada penggunaan metode transek foto bawah air. Oseanologi dan Limnologi di Indonesia, 38(1):1-18

Giyanto 2012b. Penilaian kondisi terumbu karang dengan metode transek foto bawah air. Oseanologi dan Limnologi di Indonesia, 38(3):377-390.

Helmi, M., Aysira, A., Munasik, M., Wirasatriya, A., Widiaratih, R. \& Ario, R., 2020. Spatial Structure Analysis of Benthic Ecosystem Based on Geospatial Approach at Parang Islands, Karimunjawa National Park, Central Java, Indonesia. Indonesian Journal of Oceanography, 2(1):1-7

Johansen, K., Coops, N.C., Gergel, S.E. \& Stange, Y. 2007. Application of high spatial resolution satellite imagery for riparian and forest ecosystem classification. Remote Sensing of Environment, 110(1):29-44, DOI: 10.1016/j.rse.2007.02.014.

Nababan, M.G., Munasik, I.Y., Kartawijaya, T., Prasetia, R., Ardiwijaya, R.L., Pardede, S.T., Sulisyati, R. \& Mulyadi, Y.S. 2010. Status ekosistem di Taman Nasional Karimunjawa. Wildlife Conservation Society-Indonesia Program. Bogor. xi+78hlm.

Nakamura, T. \& Nakamori, T. 2009. Estimation of photosynthesis and calcification rates at a fringing reef by accounting for diurnal variations and the zonation of coral reef communities on reef flat and slope: a case study for the Shiraho reef, Ishigaki Island, southwest Japan. Coral Reefs, 28:229-250. DOI: 10.1007/s00338-008-0454-8

Kohler, K.E. \& Gill, S.M. 2006. Coral Point Count with Excel extensions (CPCe): A Visual Basic program for the determination of coral and substrate coverage using random point count methodology. Computers and Geosciences, 32(9):1259-1269

Suharsono \& Sumadhiharga, O.K. (eds). 2014. Panduan Monitoring Kesehatan Terumbu Karang. COREMAP CTI LIPI. Jakarta. $\mathrm{x}+63 \mathrm{hlm}$. 
Takada, Y., Abe, O. \& Shibuno, T. 2012. Variations in cryptic assemblages in coral-rubble interstices at a reef slope in Ishigaki Island, Japan. Fisheries Science, 78:91-98. DOI: $10.1007 / \mathrm{s} 12562-011-0437-5$

Tomasick, T., Mah, A.J., Nontji, A. \& Moosa, M.K. 1997. The Ecology of the Indonesia Seas. Part One. Periplus Edition (HK) Ltd., Singapore.

Ventura, D., Bruno, M., Lasinio, G.J., Belluscio, A. \& Ardizzone, G. 2016. A low-cost drone-based application for identifying and mapping of coastal fish nursery grounds. Estuarine, Coastal and Shelf Science, 171: 85-98. DOI: 10.1016/j.ecss.2016.01.030.

Wilkinson, C.R. 2000. Executive summary. In C. R. Wilkinson (Ed.), Status of coral reefs of the world. Australian Institute of Marine Science. Australia

Yusidarta, I. \& Atmojo, N.D. 2018. Drone dan pengukuran kerusakan terumbu karang akibat vessel grounding di Taman Nasional Karimunjawa (Studi kasus Gosong Seloka). Prosiding Seminar Nasional Kelautan XIII, Surabaya 12 Juli 